\title{
Use of gemtuzumab ozogamycin combined with conventional chemotherapy in patients with acute myeloid leukemia
}

\section{Uso de gemtuzumabe ozogamicina combinado com quimioterapia convencional em pacientes com leucemia mieloide aguda}

\begin{abstract}
Guilherme Fleury Perini ${ }^{1}$, Fabio Pires de Souza Santos ${ }^{1}$, Iracema Esteves ${ }^{1}$, Claudia Mac-Donald Bley do Nascimento ${ }^{1}$, Morgani Rodrigues ${ }^{1}$, Reijane Alves de Assis ${ }^{1}$, Ricardo Helman ${ }^{1}$, Jose Mauro Kutner ${ }^{2}$,
\end{abstract}

Andreza Alice Feitosa Ribeiro ${ }^{2}$, Nelson Hamerschlak ${ }^{1}$

\begin{abstract}
Objective: To analyze the outcome of patients treated with gemtuzumab ozogamycin combined with conventional therapy treated at Hospital Israelita Albert Einstein. Methods: 14 patients who had high risk features (secondary leukemia, unfavorable cytogenetics, and refractory disease) were treated with gemtuzumab ozogamycin combined with conventional therapy and their outcome was analysed by reviewing their medical records. Results: Overall response rate was $58 \%$, with $43 \%$ achieving complete response, with a median followup of 11 months, event-free survival was 3 months. Eleven patients died, 6 of them due to refractory acute myeloid leukemia. Only four patients presented with grade 3 to 4 toxicities and only one patient had sinusoidal obstruction syndrome after bone marrow transplant. Conclusion: gemtuzumab ozogamycin combined with chemotherapy is a feasible treatment regimen in acute myeloid leukemia patients. However, further studies are necessary to clarify which subgroup of patients may benefit from this treatment.
\end{abstract}

Keywords: Leukemia, myeloid, acute/drug therapy; Radiotherapy; Antineoplastic agents/therapeutic use; Antineoplastic combined chemotherapy protocols/therapeutic use; Aged

\section{RESUMO}

Objetivo: Analisar a evolução de pacientes tratados com gemtuzumabe ozogamicina combinado à terapêutica convencional no Hospital Israelita Albert Einstein. Métodos: 14 pacientes que tinham alto risco (leucemia secundária, citogenética desfavorável e doença refratária) foram tratados com gentuzumabe ozogamicina associado à terapêutica convencional, e sua evolução foi analisada por meio de seus prontuários médicos. Resultados: A taxa total de resposta foi de $58 \%$, com $43 \%$ chegando a resposta completa, em acompanhamento médio de 11 meses, e três meses com intervalo de sobrevivência livre. Foram a óbito 11 pacientes, 6 deles por leucemia mieloide aguda. Somente quatro pacientes apresentaram graus 3 a 4 de toxicidade e apenas um paciente teve síndrome de obstrução sinusoidal após transplante de medula. Conclusão: Gemtuzumabe ozogamicina associado à terapêutica quimioterápica convencional é um tratamento factível em pacientes com leucemia mieloide aguda. Contudo, novos estudos são necessários para esclarecer qual 0 subgrupo de pacientes que pode se beneficiar desse tratamento.

Descritores: Leucemia mieloide aguda/quimioterapia; Radioterapia; Antineoplásicos/uso terapêutico; Protocolos de quimioterapia combinada antineoplásica/uso terapêutico; Idoso

\section{INTRODUCTION}

Current treatment of patients with acute myeloid leukemia (AML) involves administering an intensive phase of chemotherapy (induction chemotherapy) with the objective of achieving a state of complete remission (CR) which is a pre-requisite for cure ${ }^{(1,2)}$. The most traditional induction regimen consists of a combination of cytarabine (ara-C) with anthracyclines, such as daunorubicin or idarubicin $(7+3 \text { regimen })^{(2)}$. However, in elderly patients with AML (usually defined as > 5560 years of age), administering an aggressive induction course of chemotherapy can be limited by the presence of comorbidities and poor tolerance ${ }^{(3)}$. Additionally, elderly patients with AML more commonly present with poor-risk features and a high rate of resistant disease ${ }^{(3)}$. As a result, CR rates with induction chemotherapy

\footnotetext{
Study carried out at Hospital Israelita Albert Einstein - HIAE - São Paulo (SP), Brazil.

${ }^{1}$ Hematology and Bone Marrow Transplantation, Hospital Israelita Albert Einstein - HIAE - São Paulo (SP), Brazil.

${ }^{2}$ Hemotherapy, Hospital Isrealita Albert Einstein - HIAE - São Paulo (SP), Brazil; Hemathology and Bone Marrow Transplantation, Hospital Israelita Albert Einstein - HIAE - São Paulo (SP) - Brazil.

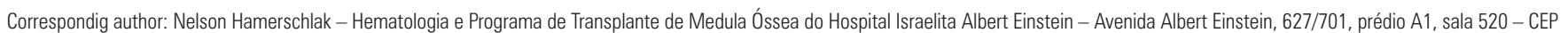
05651-901 - São Paulo (SP) Brasil - e-mail: hamer@einstein.br

Received on: Jan 15, 2011 - Accepted on: Apr 11, 2011

The authors declare there is no conflict of interest.
} 
for elderly patients with AML are in the range of 40 to $50 \%$ only, and long term survival rates are less than $10 \%(3)$. Thus, there is great need for improving therapy in elderly patients with AML.

Gemtuzumab ozogamycin (GO) (Mylotarg ${ }^{\circledR}$; Pfizer, New York, NY) is a monoclonal antibody targeted against the CD33 antigen and coupled with the chemotherapeutic agent calicheamicin ${ }^{(4)}$. CD33 is a surface molecule which is expressed on the surface of myeloid cells and in myeloid blasts of the majority of patients with $\mathrm{AML}^{(4)}$. The anti-CD33 antibody in GO is coupled with calicheamicin through an acid-sensitive linker. Calicheamicin is a compound from the enediyne class, and it induces cleavage of DNA strands through formation of free radicals ${ }^{(5)}$. Upon binding to CD33, $\mathrm{GO}$ is internalized into a lysosomal vesicle, and the acid $\mathrm{pH}$ cleaves the linker and releases calicheamicin from the monoclonal antibody ${ }^{(4)}$.

Clinical trials have shown that GO has activity in the setting of both relapsed/refractory and untreated AML. Three phase II studies enrolled 142 patients with untreated first relapsed CD33-positive $\mathrm{AML}^{(6)}$. Patients were treated with GO at a dose of $9 \mathrm{mg} / \mathrm{m}^{2}$ for one or two infusions. The CR rate was $16 \%$, and $13 \%$ achieved CR without full recovery of platelet counts (CRp) for an overall response rate (ORR) of $29 \%$. Based on this report, GO was approved as a single agent for therapy of elderly (age $\geq 60$ years) patients with relapsed $\mathrm{AML}^{(7)}$. Other reports confirmed activity of GO as a single agent ${ }^{(8-14)}$. More recently, clinical trials focused on combination of GO with other agents, including cytarabine, anthracyclines and purine analogues ${ }^{(15,16)}$. We report the experience of our institution with a combination regimen containing cytarabine and GO for treatment of elderly patients with AML.

\section{METHODS}

The outcomes of 14 patients treated with GO combined with conventional chemotherapeutic agents at Hospital Israelita Albert Einstein (HIAE), from 2007 to 2009, were reviewed. The patients had a diagnosis of AML according to the 2001 World Health Organization (WHO) classification and had either relapsed/refractory disease or untreated AML but were unable to tolerate intensive chemotherapy due to age and/or comorbidities. The patients signed an informed consent form before beginning chemotherapy. Pathology reports of bone marrow (BM) biopsies were reviewed for information about baseline hematopoietic cell dysplasia. Karyotype was stratified into good, intermediate and poor prognosis based on the most recent cytogenetic classification of the Medical Research Council (MRC).

\section{Treatment}

Fourteen patients were treated with different combinations of GO and conventional chemotherapeutic agents depending on age, comorbidities and clinical judgment. GO was administered at a dose of $3 \mathrm{mg} / \mathrm{m}^{2}$ IV, over 2 hours, on treatment days 1, 4 and 7. This fractionated regimen was first published by Taksin et al., in 2007, and differs from the initial dose schedule of GO approved by the Food and Drug Administration (FDA), in the United States ${ }^{(17)}$.

\section{Response definitions and statistical analysis}

Crieria for response and survival endpoints were previously published. Briefly, complete remission (CR) was defined by the presence of less than $5 \%$ blasts in the $\mathrm{BM}$ with more than $1 \times 10^{9} / \mathrm{L}$ neutrophils and more than $100,000 / \mathrm{mm}^{3}$ platelets in the peripheral blood $(\mathrm{PB})^{(18,19)}$. Patients with CR without platelet recovery met all criteria for $\mathrm{CR}$, except for recovery of platelet counts above $100,000 / \mathrm{mm}^{3}$. A relapse was defined by more than $5 \%$ blasts in a $\mathrm{BM}$ aspirate unrelated to recovery or by the presence of extramedullary disease. Event-free survival (EFS) was calculated from the beginning of treatment until an event. An event was defined as relapse, resistant disease and death. Induction death was defined as death occurring before achievement of CR or confirming resistant disease. Patients without an event were censored at last followup. Disease-free survival (DFS) was calculated from the time of CR until relapse or death in CR. Patients alive in CR were censored at last follow-up. Overall survival (OS) was calculated from the time of diagnosis until death. All patients alive at last follow-up were censored. Cumulative incidence of relapse and death in CR were estimated by the Gray method, taking into account competitive risks ${ }^{(20)}$. Descriptive statistics were used for baseline covariates. Survival was estimated by the Kaplan-Meier method.

\section{RESULTS}

Clinical features are summarized in table 1. Median age was 69 years (range 33 to 83 years). Fourteen patients received treatment with GO combined with conventional chemotherapeutic agents. Six patients (UPI\# 1,3,4,5,6,7) received GO combined with standard dose cytarabine $\left(100 \mathrm{mg} / \mathrm{m}^{2} \mathrm{IV}\right.$, by continuous infusion, for 7 days). One patient (UPI\#2) received GO combined with low-dose cytarabine $\left(10 \mathrm{mg} / \mathrm{m}^{2} \mathrm{IV}\right.$, for 10 days), since the patient was in the Intensive Care Unit receiving treatment for a pulmonary infection when treatment started. Median age of these patients was 
Table 1. Baseline characteristics at time of treatment

\begin{tabular}{lc}
\hline Variable & Mean (range) or No. [\%] \\
\hline Age, years & $69(33-83)$ \\
Male sex & $8[57]$ \\
Performance status 3-4 & $4[29]$ \\
Prior history of MDS & $5[36]$ \\
Therapy-related disease & $3[21]$ \\
WBC, per $\mathrm{mm}^{3}$ & $5,000(900-59,000)$ \\
Hb, g/dL & $9.4(6.5-13.5)$ \\
Platelets, per mm ${ }^{3}$ & $41,000(8,000-190,000)$ \\
Bone marrow blasts, \% & $33.6(6.4-82)$ \\
LDH, IU/L & $1,254(419-3,048)$ \\
Cytogenetics* & \\
$\quad$ Good & $0[0]$ \\
Intermediate & $9[75]$ \\
Poor & $3[25]$ \\
Dysplastic morphology in bone marrow & $7[54]$ \\
\hline
\end{tabular}

* Information on karyotype was available for 12 patients only.

MDS: myelodysplastic syndrome; WBC: white blood cell count; Hb: hemoglobin; LDHL: lactate dehydrogenase

75 years (range 64 to 83 years), and four patients had a performance status (PS) of 3 to 4 . The remaining seven patients received GO combined with chemotherapy for relapsed AML. Median number of prior therapies was 2 (range 1-3). Two patients (UPI\#8 and \#9) received GO with intermediate-dose of cytarabine $\left(600 \mathrm{mg} / \mathrm{m}^{2} \mathrm{IV}\right.$ for 5 days) and UPIN\#9 also received mitoxantrone $(10 \mathrm{mg} /$ $\mathrm{m}^{2}$ IV for 2 days). One patient (UPIN\#11) received GO combined with high-dose cytarabine $\left(3 \mathrm{~g} / \mathrm{m}^{2} \mathrm{IV}\right.$, twice daily, for 5 days) and mitoxantrone $\left(10 \mathrm{mg} / \mathrm{m}^{2} \mathrm{IV}\right.$, for 3 days). The other four patients received fractionated GO combined with cytarabine and mitoxantrone as per the MIDAM protocol (cytarabine $1 \mathrm{~g} / \mathrm{m}^{2} \mathrm{IV}$, twice daily, for 5 days; mitoxantrone $12 \mathrm{mg} / \mathrm{m}^{2} \mathrm{IV}$, once daily, for 3 days). Five patients received an allogeneic stem cell transplantation (SCT), on average 2 months after GO chemotherapy (range 1 to 5 months). Source of stem cells were double cord bloods (CB) in three cases and a matched unrelated donor (MUD) in two cases. At time of SCT, two patients had active disease, and three patients were in CR.

Overall, the rate of CR was 43\%; two patients achieved CRp for an overall response rate (ORR) of $58 \%$. Refractory disease and induction death ocurred in $21 \%$ of patients each. Median time to CR was 29 days (range 22 to 38 days). Among the seven patients who received $\mathrm{GO}$ combined with ara-C for initial induction therapy, the ORR was $43 \%$ (2 CRs + $1 \mathrm{CRp})$, one patient had resistant disease and three patients $(43 \%)$ died before response could be assessed. The ORR for GO combined with chemotherapy used as salvage was $71 \%$ (4 CRs + $1 \mathrm{CRp}$ ); two patients had refractory leukemia. A CR was obtained in two of three patients who presented with poor-risk cytogenetics; among the remaining nine patients with intermediate-risk karyotype, the ORR was $67 \%$.

Median follow-up of surviving patients was 11 months. Survival estimates are presented on figures 1 to 3. Eleven patients have either died of or relapsed, for a median EFS of 3 months (95\%CI: 0-6.6 months). Eleven patients $(79 \%)$ died, six of them $(54 \%)$ due to refractory AML and the remainder due to treatmentrelated toxicity (three deaths were due to GO and chemotherapy). The median OS was 4 months (95\% CI 0-9.5 months). For the eight patients who had a response, median DFS was 10 months (95\%CI: 2.617.3 months). Among the three survivors at the time of this report, two received consolidation with an allogeneic double CB transplant at the time of CR. The cumulative incidence of relapse for responding patients was $42.5 \%$ (95\% CI: 6.9-75.9\%) at 1 year, and the cumulative incidence of death in CR at 1 year was $21 \%$ (95\% CI $0.4 \%-44.4 \%)$.

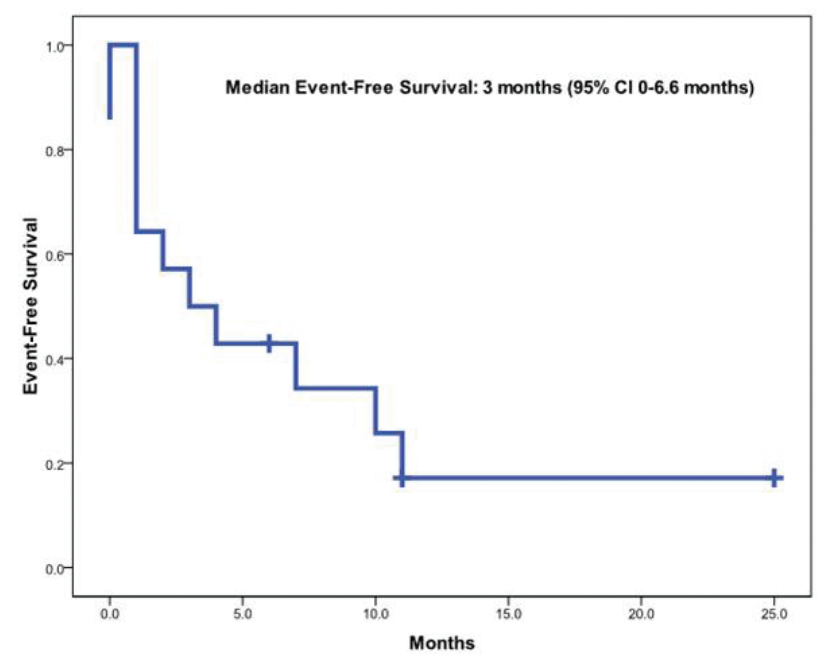

Figure 1. Event-free survival

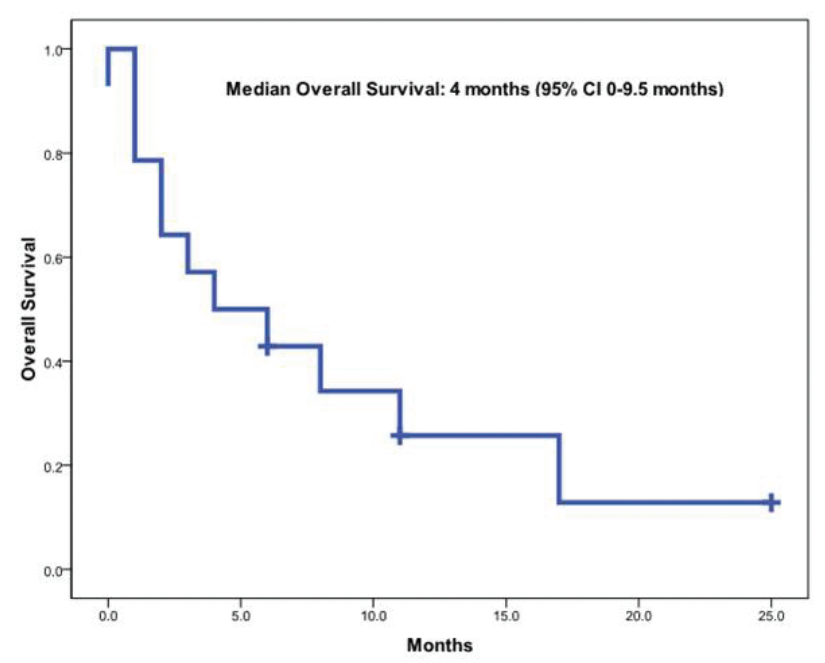

Figure 2. Overall survival 


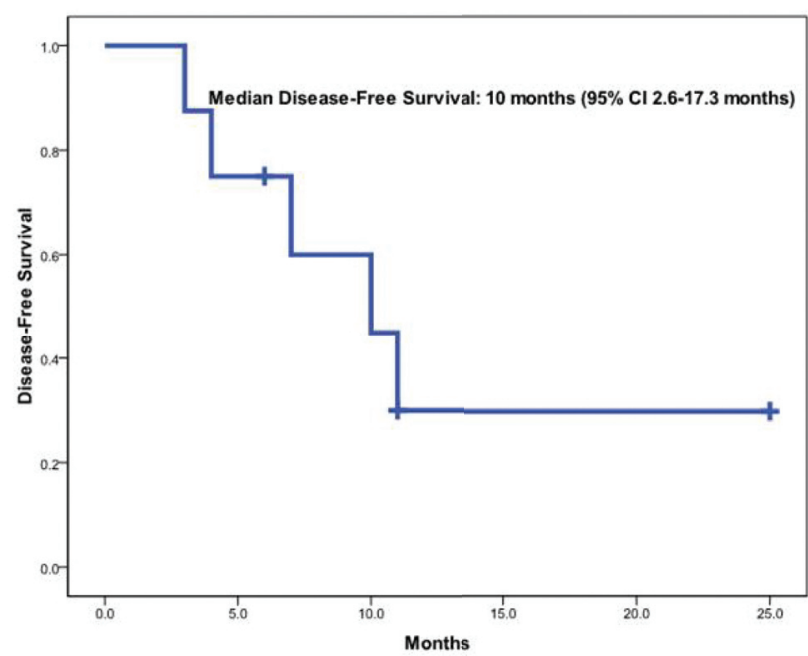

Figure 3. Disease-free survival
As expected, myelosuppressive toxicity was paramount, with universal incidence of grade 3 to 4 neutropenia and thrombocytopenia. In patients who achieved $\mathrm{CR}$, median time to neutrophil recovery (ANC $\geq 1,000 / \mathrm{mm}^{3}$ for, at least, 2 consecutive days) was 23 days (range 18 to 29 days), and median time to platelet recovery was 35 days (range 22 to 66 days). Grade 3 to 4 hepatic toxicity was observed in three patients, one with grade 3 elevation in bilirubin and grade 4 elevation in gamma-GT and alkaline phosphatase, and two with grade 3 elevation in gamma-GT. No patient developed sinusoidal obstruction syndrome (SOS) while on therapy with GO, but one patient developed SOS post allogeneic MUD SCT two months post-GO.

Chart 1 shows the treatment and outcome of the patients.

Chart 1. Treatment and outcome of each patient

\begin{tabular}{|c|c|c|c|c|c|}
\hline $\mathbf{P t}$ & Cytogenetics & Induction & EFS & OS & Comments \\
\hline 1 & $\begin{array}{l}43 \sim 46, X Y,+2,-4, \operatorname{add}(5)(q 33) \\
-7, \operatorname{der}(16),+2 \text { mar,inc[cp17] }\end{array}$ & $\mathrm{GO}+\mathrm{SD}$ ara-C & 7.0 & 8.0 & 1st line \\
\hline 2 & $46, X Y$ & $\mathrm{GO}+\mathrm{LD}$ ara-C & 1.0 & 1.0 & 1st line \\
\hline 3 & $\begin{array}{l}\text { 47,XX,der(21;22)(q10;q10), } \\
+\operatorname{der}(21 ; 22)(q 10 ; q 10) \times 2[17]\end{array}$ & $\mathrm{GO}+\mathrm{SD}$ ara-C & 10.0 & 17.0 & 1st line \\
\hline 4 & ND & $\mathrm{GO}+\mathrm{SD}$ ara $-\mathrm{C}$ & 0.0 & 0.0 & 1st line \\
\hline 5 & $46, X Y$ & $\mathrm{GO}+\mathrm{SD}$ ara- $\mathrm{C}$ & 4.0 & 6.0 & Post-MDS AML; had previously received DAC/AZA for high-grade MDS \\
\hline 6 & $46, X Y$ & $\mathrm{GO}+\mathrm{SD}$ ara-C & 1.0 & 2.0 & 1st line; NPM1 +/FLT3-D835+ \\
\hline 7 & ND & $\mathrm{GO}+\mathrm{SD}$ ara- $\mathrm{C}$ & 1 & 1 & $\begin{array}{l}\text { Transferred from another hospital; had } 95 \% \text { blasts in PB at time of } \\
\text { diagnosis; no BM aspirate or cytogenetics at time of presentation }\end{array}$ \\
\hline 8 & $\begin{array}{l}\text { 46,XX,del(5) (q12q32),add(13)(p13), } \\
\quad-13,-20+\operatorname{mar} 1 \times 2[15] / 46, X X[5]\end{array}$ & $\mathrm{GO}+\mathrm{ID}$ ara-C & 0 & 2 & $\begin{array}{l}\text { History of ovarian cancer, developed t-MDS, later t-AML; received } \\
\text { induction with } 7+3 \times 2 \text {; came with resistant disease in an MDS state } \\
\text { (6.4\% blasts); allo CB SCT in August } 2008 \text {, died of complications }\end{array}$ \\
\hline 9 & $46, X Y$ & $\mathrm{GO}+\mathrm{ID}$ ara- $\mathrm{C}+\mathrm{MTZ}$ & 11 & 11 & $\begin{array}{l}\text { Relapsed post-Auto-SCT; entered CR with GO+Ara-C+MTZ; received } \\
\text { Allo MUD SCT in October 2008; died of GVHD in March } 2009\end{array}$ \\
\hline 10 & $46, X X, \operatorname{del}(7)(q 22)$ & MIDAM & 3 & 3 & $\begin{array}{l}\text { Diagnosis of AML-M2, CR with 7+3, relapsed with -7, received FLAG- } \\
\text { Ida but was refractory; entered CR with MIDAM and went to MUD Allo } \\
\text { SCT in May 2009; died of SCT-related complications }\end{array}$ \\
\hline 11 & $46, X X$ & GO+HD Ara-C+MTZ & $25.0+$ & $25.0+$ & $\begin{array}{c}\text { Acute erythroleukemia; prior ASCT; \% of blasts among non-erythroid } \\
\text { cells; underwent allogeneic double CB stem cell transplantation on } \\
\text { February } 09\end{array}$ \\
\hline 12 & 46,XX,inv(9) (p12q13)[20] & MIDAM & 2 & 4 & $\begin{array}{l}\text { Refractory AML; received MIDAM and was refractory; Allo-SCT in } \\
\text { October 2009; died of SCT complications in December } 2009\end{array}$ \\
\hline 13 & $46, X Y$ & MIDAM & $6+$ & $6+$ & $\begin{array}{c}\mathrm{NPM} 1+/ \text { FLT3- AML; refractory to 7+3; entered CR with MIDAM; on } \\
\text { maintenance with 5-azacitidine }\end{array}$ \\
\hline 14 & $46, X X$ & MIDAM & $11+$ & $11+$ & $\begin{array}{l}\text { NPM1 +/FLT3 + AML; refractory to 7+3; entered CR with MIDAM; } \\
\text { allogeneic double cord SCT on July } 2010\end{array}$ \\
\hline
\end{tabular}

HD: high dose; SD: standard dose; ID: intermediate dose; LD: low dose.

EFS: event free survival; OS: overall survival; MDS: myelodysplastic syndrome; AML: acute myeloid leukemia; DAC: decitabine; AZA: 5-azacytidine; PB: peripheral blood; BM: bone marrow; CB: cord blood; ASCT: autologous stem cell transplantation; GO: gemtuzumab ozogamycin; Ara-c Mitoxantrone; MTZ: mitoxantrone; GVHD: graft versus host disease; MIDAM: mylotarg; 


\section{DISCUSSION}

In our experience, GO combined with chemotherapy proved to be feasible regimen, with a low incidence of grade 3 to 4 toxicities. Yet, long term results confirm the need for improving consolidation treatment and maintaining response after achievement of CR.

It is still controversial whether treatment with $\mathrm{GO}$ has any benefits in the therapy of patients with AML. Recently, Pfizer has withdrawn GO from the market, due to disappointing results observed in a phase III trial ${ }^{(21)}$. In this study, the addition of GO to induction therapy or as post-consolidation therapy did not improve the CR rate, relapse-free survival (RFS), post-consolidation DFS, or OS, but was associated with a significantly higher risk of fatal induction adverse events.

It is well known that AML is an heterogeneous disease with distinct subtypes identified by morphological, chromosomal and genetic abnormalities ${ }^{(22)}$. Distinct subtypes of AML may respond differently to a particular drug or chemotherapy regimen. It is also well-known, for instance, that core-binding factor abnormalities, NPM1 mutations (and possible Ras mutations also), may identify subgroups of patients with AML who respond better to high dose cytarabine in consolidation, while the same regimen is supposedly poorly effective in patients with high-risk chromosomal abnormalities ${ }^{(23-25)}$. It is thus important to further discern which subgroup of patients can benefit from GO. A recent published study analyzed patients enrolled in a phase III trial of the MRC, focusing on this issue. In this study, patients with CBF AML (favorable-risk karyotype) showed significantly better results with the association of GO $\left(3 \mathrm{mg} / \mathrm{m}^{2}\right)$ during induction chemotherapy ${ }^{(26)}$. The same results were observed in a preliminary analysis of the other phase III trial mentioned above ${ }^{(21)}$. It has been postulated that GO may overcome the negative impact of KIT mutations in patients with CBF AML. In the MRC clinical trial, GO did not improve the outcome of patients with high-risk karyotype AML, which further suggests that new treatment options are urgently needed for this subgroup of patients.

\section{CONCLUSION}

Combining GO with conventional chemotherapy had a modest efficacy in our cohort of patients. We believe that GO is a compound which may benefit selected patients with AML. New trials are necessary to evaluate the role of GO in patients with favorable-risk karyotype AML.

\section{REFERENCES}

1. Walter RB, Kantarjian HM, Huang X, Pierce SA, Sun Z, Gundacker HM, et al. Effect of complete remission and responses less than complete remission on survival in acute myeloid leukemia: a combined Eastern Cooperative Oncology Group, Southwest Oncology Group, and M. D. Anderson Cancer Center Study. J Clin Oncol. 2010;28(10):1766-71.

2. Döhner $H$, Estey EH, Amadori $S$, Appelbaum FR, Büchner T, Burnett AK, Dombret H, Fenaux P, Grimwade D, Larson RA, Lo-Coco F, Naoe T, Niederwieser D, Ossenkoppele GJ, Sanz MA, Sierra J, Tallman MS, Löwenberg B, Bloomfield CD; European LeukemiaNet. Diagnosis and management of acute myeloid leukemia in adults: recommendations from an international expert panel, on behalf of the European LeukemiaNet. Blood. 2010;115(3):453-74.

3. Kantarjian H, Ravandi F, OBrien S, Cortes J, Faderl S, Garcia-Manero $\mathrm{G}$, et al. Intensive chemotherapy does not benefit most older patients (age 70 years or older) with acute myeloid leukemia. Blood. 2010;116(22):4422-9.

4. Tsimberidou AM, Giles FJ, Estey E, O’Brien S, Keating MJ, Kantarjian HM. The role of gemtuzumab ozogamicin in acute leukaemia therapy. $\mathrm{Br} J$ Haematol. 2006;132(4):398-409.

5. Zein N, Sinha AM, McGahren WJ, Ellestad GA. Calicheamicin gamma 11: an antitumor antibiotic that cleaves double-stranded DNA site specifically. Science. 1988;240(4856):1198-201.

6. Sievers EL, Larson RA, Stadtmauer EA, Estey E, Löwenberg B, Dombret $H$, Karanes C, Theobald M, Bennett JM, Sherman ML, Berger MS, Eten CB, Loken MR, van Dongen JJ, Bernstein ID, Appelbaum FR; Mylotarg Study Group. Efficacy and safety of gemtuzumab ozogamicin in patients with CD33-positive acute myeloid leukemia in first relapse. J Clin Oncol. 2001;19(13):3244-54.

7. Bross PF, Beitz J, Chen G, Chen XH, Duffy E, Kieffer L, et al. Approval summary: gemtuzumab ozogamicin in relapsed acute myeloid leukemia. Clin Cancer Res. 2001;7(6):1490-6.

8. Amadori S, Suciu S, Selleslag D, Stasi R, Alimena G, Baila L, et al. Randomized trial of two schedules of low-dose gemtuzumab ozogamicin as induction monotherapy for newly diagnosed acute myeloid leukaemia in older patients not considered candidates for intensive chemotherapy. A phase II study of the EORTC and GIMEMA leukaemia groups (AML-19). Br J Haematol. 2010;149(3):376-82.

9. Amadori S, Suciu S, Stasi R, Willemze R, Mandelli F, Selleslag D, et al. Gemtuzumab ozogamicin (Mylotarg) as single-agent treatment for frail patients 61 years of age and older with acute myeloid leukemia: final results of AML-15B, a phase 2 study of the European Organisation for Research and Treatment of Cancer and Gruppo Italiano Malattie Ematologiche dellAdulto Leukemia Groups. Leukemia. 2005;19(10):1768-73.

10. Breccia M, Cimino G, Diverio D, Gentilini F, Mandelli F, Lo Coco F. Sustained molecular remission after low dose gemtuzumab-ozogamicin in elderly patients with advanced acute promyelocytic leukemia. Haematologica. 2007;92(9):1273-4.

11. Cohen AD, Luger SM, Sickles C, Mangan PA, Porter DL, Schuster SJ, et al. Gemtuzumab ozogamicin (Mylotarg) monotherapy for relapsed AML after hematopoietic stem cell transplant: efficacy and incidence of hepatic veno-occlusive disease. Bone Marrow Transplant. 2002;30(1):23-8.

12. McHayleh W, Foon K, Redner R, Sehgal R, Raptis A, Agha M, et al. Gemtuzumab ozogamicin as first-line treatment in patients aged 70 years or older with acute myeloid leukemia. Cancer. 2010;116(12):3001-5.

13. Piccaluga PP, Martinelli G, Rondoni M, Malagola M, Gaitani S, Isidori A, et al. Gemtuzumab ozogamicin for relapsed and refractory acute myeloid leukemia and myeloid sarcomas. Leuk Lymphoma. 2004;45(9):1791-5.

14. Schwarz J, Marková J, Peková S, Trnková Z, Sponerová D, Cetkovský P. A single administration of gemtuzumab ozogamicin for molecular relapse of acute promyelocytic leukemia. Hematol J. 2004;5(3):279-80. 
15. Chevallier P, Delaunay J, Turlure P, Pigneux A, Hunault M, Garand R, et al. Long-term disease-free survival after gemtuzumab, intermediate-dose cytarabine, and mitoxantrone in patients with $\mathrm{CD} 33(+)$ primary resistant or relapsed acute myeloid leukemia. J Clin Oncol. 2008;26(32):5192-7.

16. Tsimberidou A, Estey E, Cortes J, Thomas D, Faderl S, Verstovsek $S$, et al. Gemtuzumab, fludarabine, cytarabine, and cyclosporine in patients with newly diagnosed acute myelogenous leukemia or high-risk myelodysplastic syndromes. Cancer. 2003;97(6):1481-7.

17. Taksin AL, Legrand O, Raffoux E, de Revel T, Thomas X, Contentin N, et al. High efficacy and safety profile of fractionated doses of Mylotarg as induction therapy in patients with relapsed acute myeloblastic leukemia: a prospective study of the alfa group. Leukemia. 2007;21(1):66-71.

18. Cheson BD, Cassileth PA, Head DR, Schiffer CA, Bennett JM, Bloomfield CD, et al. Report of the National Cancer Institute-sponsored workshop on definitions of diagnosis and response in acute myeloid leukemia. J Clin Oncol. 1990;8(5):813-9.

19. Cheson BD, Bennett JM, Kopecky KJ, Büchner T, Willman CL, Estey EH, Schiffer CA, Doehner H, Tallman MS, Lister TA, Lo-Coco F, Willemze R, Biondi A, Hiddemann W, Larson RA, Löwenberg B, Sanz MA, Head DR, Ohno R, Bloomfield CD; International Working Group for Diagnosis, Standardization of Response Criteria, Treatment Outcomes, and Reporting Standards for Therapeutic Trials in Acute Myeloid Leukemia. Revised recommendations of the International Working Group for Diagnosis, Standardization of Response Criteria, Treatment Outcomes, and Reporting Standards for Therapeutic Trials in Acute Myeloid Leukemia. J Clin Oncol. 2003;21(24):4642-9. Erratum in: J Clin Oncol. 2004 Feb 1;22(3):576

20. Gray RJ. A class of K-sample tests for comparing the cumulative incidence of a competing risk. Ann Stat. 1988;16:1140-54.
21. Petersdorf S, Kopecky K, Stuart RK, Larson RA, Nevill TJ, Stenke L, et al. Preliminary Results of Southwest Oncology Group Study S0106: An International Intergroup Phase 3 Randomized Trial Comparing the Addition of Gemtuzumab Ozogamicin to Standard Induction Therapy Versus Standard Induction Therapy Followed by a Second Randomization to Post-Consolidation Gemtuzumab Ozogamicin Versus No Additional Therapy for Previously Untreated Acute Myeloid Leukemia [abstract]. Blood. 2009 November 20, 2009;114(22).

22. Marcucci G, Haferlach T, Döhner $H$. Molecular genetics of adult acute myeloid leukemia: prognostic and therapeutic implications. J Clin Oncol. 2011;29(5):475-86.

23. Bloomfield CD, Lawrence D, Byrd JC, Carroll A, Pettenati MJ, Tantravahi $R$, et al. Frequency of prolonged remission duration after high-dose cytarabine intensification in acute myeloid leukemia varies by cytogenetic subtype. Cancer Res. 1998;58(18):4173-9.

24. Neubauer A, Maharry K, Mrozek K, Thiede C, Marcucci G, Paschka P, et al. Patients with acute myeloid leukemia and RAS mutations benefit most from postremission high-dose cytarabine: a Cancer and Leukemia Group B study. J Clin Oncol. 2008;26(28):4603-9.

25. Schlenk RF, Döhner K, Krauter J, Fröhling S, Corbacioglu A, Bullinger L, Habdank M, Späth D, Morgan M, Benner A, Schlegelberger B, Heil G, Ganser A, Döhner H; German-Austrian Acute Myeloid Leukemia Study Group. Mutations and treatment outcome in cytogenetically normal acute myeloid leukemia. N Engl J Med. 2008;358(18):1909-18.

26. Burnett AK, Hills RK, Milligan D, Kjeldsen L, Kell J, Russell NH, et al. Identification of patients with acute myeloblastic leukemia who benefit from the addition of gemtuzumab ozogamicin: Results of the MRC AML15 Trial. J Clin Oncol. 2011;29(4):369-77. 